\title{
The versatility of mesenchymal stem cells: From regenerative medicine to COVID, what is next?
}

\author{
Thaís CASAGRANDE PAIM; MÁrcia RosÂNgELA WINK* \\ Laboratório de Biologia Celular, Universidade Federal de Ciências da Saúde de Porto Alegre (UFCSPA), Porto Alegre, 90050-170, Brazil
}

Key words: Mesenchymal stem cells, Regenerative medicine, Secretome, Biomaterials, Extracellular vesicles

\begin{abstract}
Mesenchymal stem cells (MSCs) play key roles in regenerative medicine by promoting tissue healing. MSCs can be isolated from different adult tissues and they are able to differentiate into several lineages. Due to their antiinflammatory, angiogenic and immune-modulatory properties, MSCs are suitable for tissue engineering applications and, when associated with biomaterials, their benefits can be improved. Moreover, recently, MSCs have been studied for new clinical applications, such as in the treatment of patients with COVID-19. MSCs regenerative potential has been attributed to their secretome, which comprises extracellular matrix, soluble proteins and several elements, including the release of extracellular vesicles. Even though, in order to explore all their therapeutic potential, it is still necessary to advance in the investigation of their basic cell biology characteristics.
\end{abstract}

\section{Viewpoint}

Mesenchymal stem cells (MSCs) are multipotent cells found in adult tissues. They are characterized by their adherence to plastic, multilineage differentiation, and immunophenotype (Dominici et al., 2006; Galgaro et al., 2021; Song et al., 2020). Since their discovery, MSCs have been extensively studied, mainly in the last decade. A brief timeline of the main highlights of the MSCs research can be observed in Fig. 1. MSCs were initially isolated from bone marrow, but they can actually be isolated from virtually all tissues (da Silva et al., 2006). This represents a great opportunity for basic and translational studies, once it is possible to isolate MSCs from human tissues that are usually discarded after surgery procedures, such as skin, adipose tissue, umbilical cord, placenta, dental pulp, and sclerocorneal limbus (Fig. 2) (Dominici et al., 2006; Galgaro et al., 2021; Song et al., 2020).

MSCs have anti-inflammatory, angiogenic, and immunemodulatory properties that play an important role in wound healing and regeneration (Chang et al., 2021). Preclinical and clinical studies have demonstrated their promising potential to treat degenerative diseases, such as Alzheimer's disease, autoimmune diseases, bone and cartilage diseases, as well as, respiratory, cardiovascular, kidney and liver diseases (Brown et al., 2019; Samadi et al., 2021). The therapeutic effects of

\footnotetext{
*Address correspondence to: Márcia Rosângela Wink, mwink@ufcspa.edu.br

Received: 30 July 2021; Accepted: 26 September 2021
}

MSCs can be credited to three key mechanisms of action: 1) "homing", of the cells to the injury site; 2) cell differentiation, to promote repair of the damaged tissue; and 3) the secretion of bioactive factors (Vizoso et al., 2017). MSCs can also modulate the host foreign-body immunogenic reaction toward the engineered constructs. These characteristics make them attractive for tissue engineering applications (Chen and Liu, 2016; Hanson et al., 2014).

The combination of stem cells with biomaterials is a promising strategy for tissue regeneration as evidenced by several studies (Sierra-Sánchez et al., 2021). Thus, our group has also contributed with the literature, evaluating the association among different scaffolds and MSCs. In our studies, we have found that Bioglass 45S5 associated with adipose-derived MSCs (ADSCs) is suitable to be tested in preclinical studies for bone regeneration. MSCs maintained their viability, natural morphology, and osteoinduction potential after exposure to Bioglass 45S5 extract. They also grew attached to the bioglass for a long time in vitro. Moreover, the biocompatibility of bioglass samples as scaffolds for allogeneic MSCs was confirmed after subcutaneous implantation in mice (Rodrigues et al., 2019). ADSCs were also evaluated after contact with samples of 99.95\% and $99.5 \%$ pure iron for cardiovascular stents. The viability, proliferation, and morphology of ADSCs were not affected in vitro after contact with iron (Paim et al., 2020).

The use of MSCs isolated or in combination with different scaffolds is another promising strategy to treat cutaneous diseases and injuries (Sierra-Sánchez et al., 2021). 


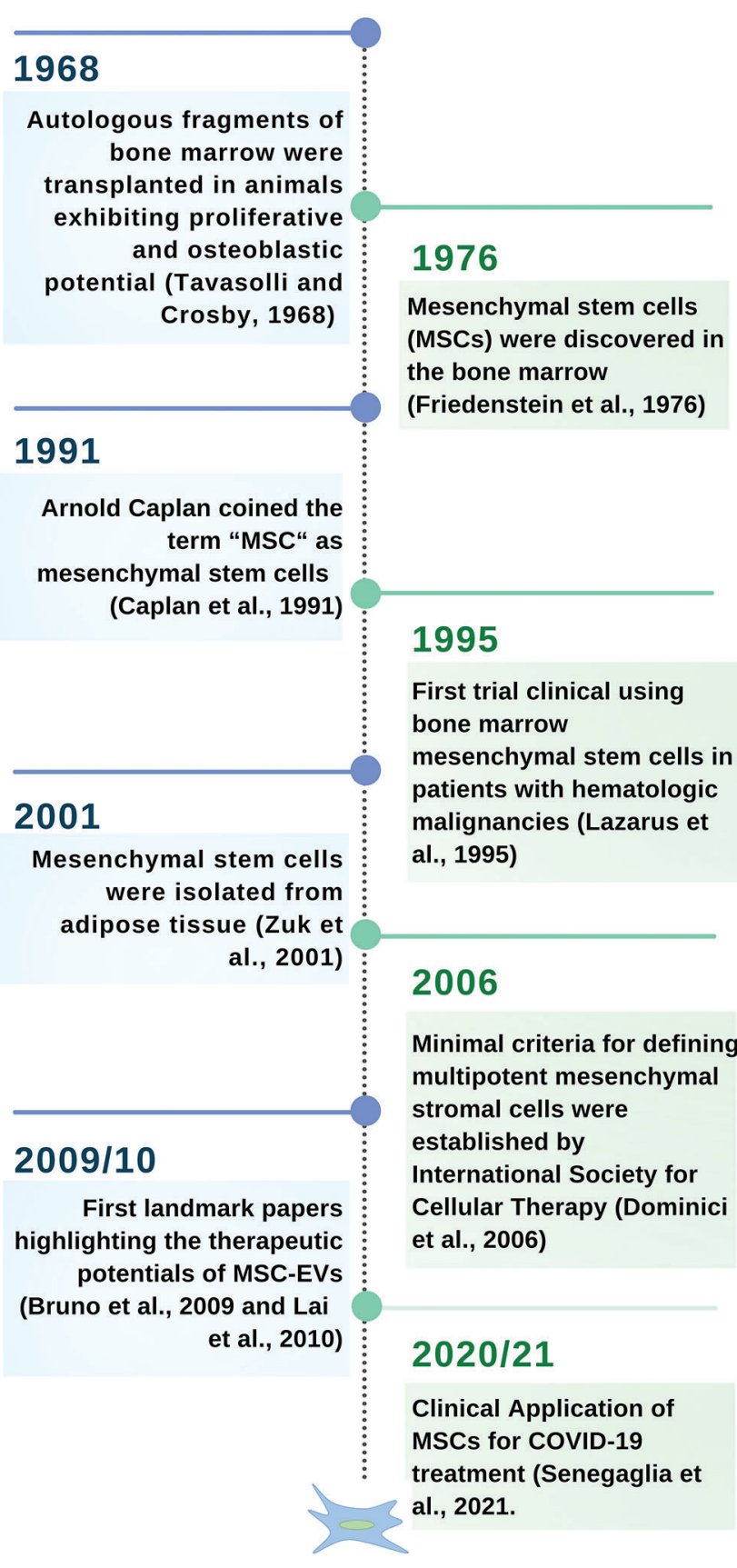

FIGURE 1. A brief timeline of MSCs.

In this setting, our research group evaluated the adhesion, morphology, and viability of ADSCs in a film composed of chitosan, gelatin, and liposomes (Vedovatto et al., 2020). Our results suggested that the biomaterial was suitable for drug delivery and promoted the growth of MSCs without cell damage. In addition, the ADSCs were also studied in combination with CMC (sodium carboxymethylcellulose), a synthetic polymer used in the treatment of skin wounds. There was no significant toxicity or DNA damage on cells cultured with CMC. The association tested as a therapy in a preclinical model contributed to wound healing of skin lesions without overproduction of collagen that could cause a fibrosis (Rodrigues et al., 2014). In addition, ADSCs could also proliferate in vitro on the human amniotic membrane (hAM), a biological scaffold generally discarded following the birth. There were no changes in their morphology, as well as, no losses on their potential of multilineage differentiation. These results indicate that hAM can be tested as a scaffold for MSCs in clinical applications (Naasani et al., 2019).

Many efforts have also been put into reproducing the corneal stroma to find an alternative to corneal transplantation (Alió del Barrio et al., 2021). We evaluated decellularized hAM and porcine small intestine submucosa (SIS) as scaffolds for limbal stroma-MSCs (L-MSCs), aiming to compare their performance for application in corneal regeneration. Both biological matrices maintained the cell viability, actin cytoskeleton, nuclei morphology, and mesenchymal phenotype. Nevertheless, there was a slight increase in the percentages of negative markers for L-MSCs grown on the SIS membrane for two weeks, in comparison to hAM, which was able to maintain the MSCs phenotype for a longer time. Besides, the hAM-L-MSCs construct was more transparent, which is an important characteristic to treat corneal injury (Sous Naasani et al., 2018).

In our opinion, while there are many reports in the literature about the MSCs applications, it is not clear yet, whether their regenerative potential is due to the cell itself, their secretome or the combination of both. Regarding the MSCs immunomodulatory properties, researchers have shown that they can be attributed to the secretome (Bruno et al., 2015; Dabrowska et al., 2020). The proteins released into the microenvironment include active factors such as cytokines, chemokines, and growth factors. They can also be released encapsulated in extracellular vesicles (EVs), classified as apoptotic bodies, microvesicles (100-1000 nm), and exosomes (30-200 nm) (Harrell et al., 2019). These EVs are essential to cell-cell communication, once they can carry proteins, lipids, mRNAs, and microRNAs (miRNAs) in the inner core (Groot and Lee, 2020).

Recently, several studies are revealing that extracellular vesicles secreted from MSCs have a critical therapeutic role. MSC-derived EVs have been reported in the treatment of osteoarthritis (Kim et al., 2021; Li et al., 2021), renal injury (Birtwistle et al., 2021), traumatic brain injury (Yang et al., 2017), lung injury (Huang et al., 2019) and liver fibrosis (Chiabotto et al., 2020). The regenerative potential of MSCsEVs was also shown in cartilage, bone, and periodontium (Cooper et al., 2019; Gholami et al., 2021). The potential of MSCs and their extracellular vesicles, microvesicles, or exosomes is largely explored in clinical trials. Currently, there are over 50 phases III or IV protocols registered in clinicaltrials.gov (ongoing or completed), using MSCs from different sources, a similar proportion of allogeneic and autologous cells, and a range of variable approaches (Table S1).

One specific cargo carried by the MSC-derived EVs are the miRNAs, which are non-coding RNAs (ncRNAs) They act on post-transcriptional regulation of gene expression allowing the restoration of the injured tissue, as other effects (Saliminejad et al., 2019). Several miRNAs are important regulators of gene expression during osteogenic and chondrogenic differentiation. Dysregulation of miRNA mediated mechanisms is related to the development of osteoporosis, bone fractures, and tumors (Iaquinta et al., 2021). Recently, Marupanthorn found that inhibition of 

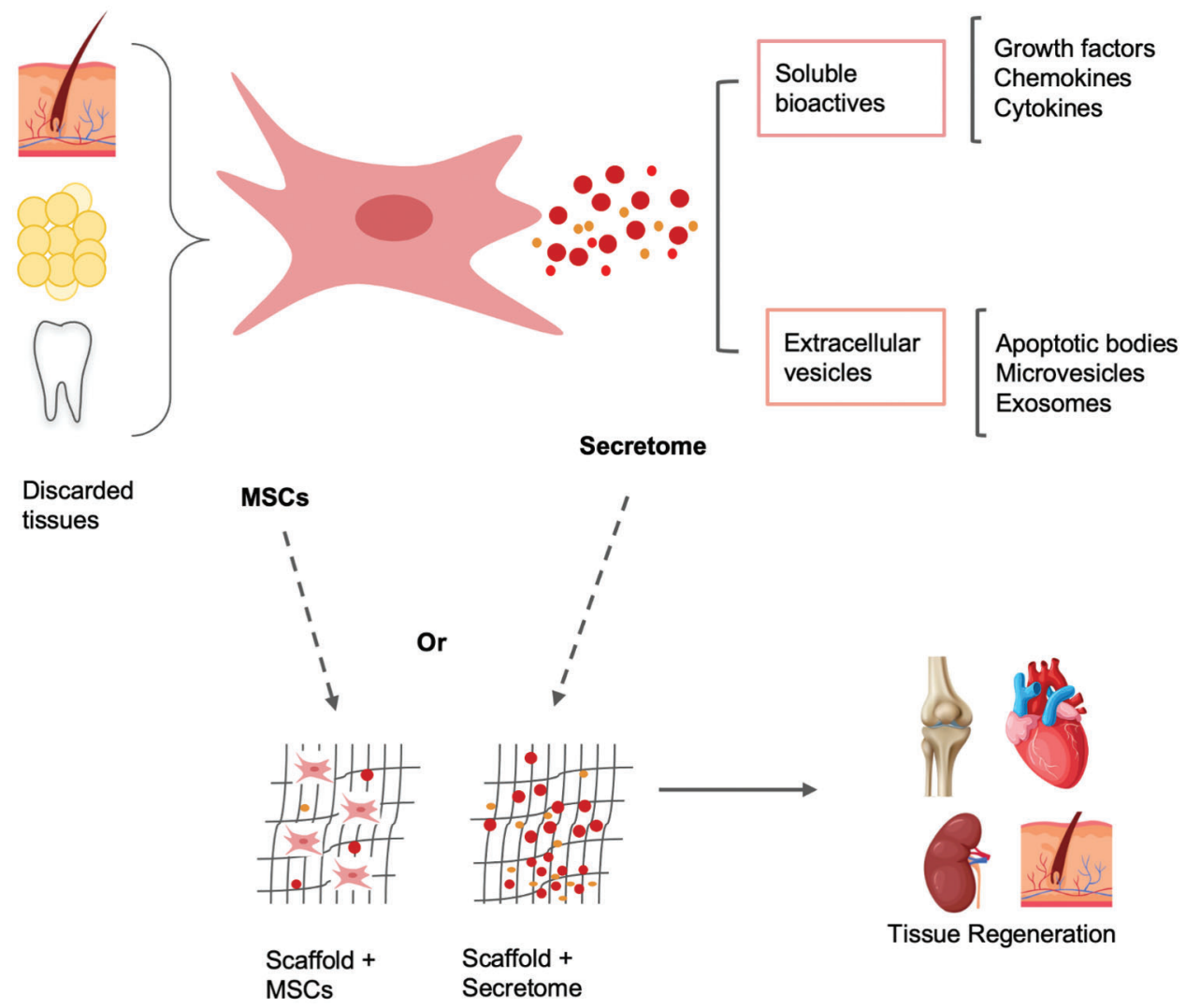

FIGURE 2. MSCs can be isolated from the discarded tissues such as: placenta, umbilical cord, teeth, adipose tissue, skin and sclerocorneal limbus. These cells secrete soluble bioactives and extracellular vesicles. MSCs or their secretome can be associated with biomaterials and promote tissue regeneration.

specific miRNAs (miR-31, miR-106a, and miR-148a) can promote osteogenic differentiation of chorion-derived mesenchymal stem cells (CH-MSCs) and placenta-derived mesenchymal stem cells (PL-MSCs) (Marupanthorn et al., 2021). Likewise, Zhang showed that the silencing of miRNA-132-3p expression in the bone tissues can promote bone marrow-derived mesenchymal stromal cells (BMSC) osteogenic differentiation and osteogenesis in mice with osteopenia (Hu et al., 2020). For this reason, miRNAs can be therapeutic targets to promote bone regeneration in osteogenesis-related disorders.

Currently, the MSCs-EVs have been studied to treat COVID-19 (O'Driscoll, 2020). The analysis of the miRNAs cargo carried by the MSC-EVs showed that they may reduce inflammatory responses, inhibit cell death genes and key factors of the coagulation cascade, preventing tissue damage and coagulation disturbances (Schultz et al., 2021). MSCs can be administered as monotherapy or in association with other treatments. As an example, Tocilizumab, a monoclonal antibody against interleukin-6, in association with an advanced therapy product, based on umbilical cordderived mesenchymal stromal cells (UC-MSC) was used to treat a severe COVID-19 patient. This therapeutic strategy promoted the decrease of inflammatory cytokines, the increase of regulatory cells, leading to lung repair (Senegaglia et al., 2021). The presence of exosomes derived from UC-MSCs, in combination with Tocilizumab may be responsible for an additive or synergistic anti-inflammatory effect, which was translated in the improvement observed in this COVID-19 patient (Schultz et al., 2021).

Another type of non-coding RNA (ncRNA), also present in MSCs, is the circular RNA (circRNA), which seem to be involved in tissue damage repair. Sun et al. (2018) observed an abundant expression and up-regulation of circRNAs, during the repair of human endometrial stromal cells (ESCs) by Wharton's jelly-derived MSCs (WJ-MSCs), leading to the enhance of the endometrial regeneration. Likewise, another recent study from the same group showed that circ6401 was significantly upregulated in WJ-MSCs co-cultured with damaged ESCs. The overexpression of circ6401 increased the levels of VEGFR2 and RAP1B in WJ-MSCs, promoting angiogenesis and proliferation of the damaged ESCs (Shi et al., 2020).

In the recent COVID-19 scenario, the MSCs performance in clinical study protocols was a great surprise. This new open avenue begs the question, what is the next? It is notorious that MSCs have a promising use in different fields of medicine, however basic questions still remain to be answered. While the phenotype of MSCs isolated from different tissues seems very similar, they are not functionally identical (Iser et al., 2014; Naasani et al., 2017). This can explain, for example, the differences in therapeutic potential according to MSC origin (Eiró et al., 2014; Vieira et al., 2010). The secretome composition of stem cells can vary regarding different factors, such as species, tissue source, donor age, protocols for MSCs isolation, culture methods, and therapeutic protocol. Immortalization, an interesting strategy for reducing the need for primary isolation, also changes important characteristics, mainly related to levels of the extracellular adenosine, a potent immunosuppressor (Beckenkamp et al., 2020). Another important aspect to be taken into consideration is the cell microenvironment. It includes the biochemical (e.g., growth factors, small bioactive molecules, and genetic regulators) and biophysical (e.g., pore size, porosity, stiffness, and topography of the 
biomaterial) stimuli to which the cells are exposed (Brown et al., 2019; Chen and Liu, 2016; Daneshmandi et al., 2020). Moreover, the extracellular matrix, one of the most important components of the niche environmental signals, can impact the proliferation and differentiation of MSCs (Assis-Ribas et al., 2018; Novoseletskaya et al., 2020).

Therefore, there are important questions to be addressed before using MSCs as a cellular therapy to ensure clinical safety and efficacy: (1) Is it better to use autologous MSCs than allogeneic? (2) Are the MSCs from different donors functionally identical? (3) Are there differences between MCSs derived from young or old donors? (4) Is there relevance in the gender of the donor? (5) Can the body mass index (BMI) of donors influence the MCS performance? (6) What is the best tissue for cell isolation? (7) What is the best protocol, cultured MSCs or directly collected? (8) Is there a way of immortalizing MSCs that does not change their key functions? (9) When culturing and expanding MSCs, what is the best growth medium for clinical application? (10) What is the most suitable administration route? (11) How many cells need to be applied? (12) How many cell infusions are necessary? Answering all these variables that can impact clinical success, and other still open questions regarding the MSCs basic cell biology is the key to advance in the next therapeutic challenges.

Acknowledgement: We are grateful to MSc. Iago Carvalho Schultz and Dr. Guido Lenz for critical reading and suggestions to the manuscript. Fig. 2 has elements designed by macrovector/Freepik.

Authors' Contribution: The authors confirm responsibility for the following: viewpoint and manuscript preparation.

Funding Statement: This study was financed in part by the Coordenação de Aperfeiçoamento de Pessoal de Nível Superior - Brasil (CAPES)-Finance Code 001; TCP is fellowship from $\mathrm{PhD}$ CAPES (Coordenação de Aperfeiçoamento de Pessoal de Nivel Superior); MRW is recipient of 1D level research fellowship from $\mathrm{CNPq}$ (Conselho Nacional de Desenvolvimento Científico e Tecnológico); This study was supported by $\mathrm{CNPq}$, MS-SCTIE-Decit/CNPq no 12/2018 (441575/2018-8) and MSSCTIE-DECIT-DGITIS-CGCIS/CNPq no 26/2020 (442586/ 2020-5); and by Fundação de Amparo à Pesquisa do Estado do Rio Grande do Sul-Brasil (FAPERGS/CAPES 06/2018Programa de Internacionalização da pós-graduação no RS (19/2551-0000679-9).

Conflicts of Interest: The authors declare that they have no conflicts of interest to report regarding the present study.

\section{References}

Alió Del Barrio JL, Arnalich-Montiel F, de Miguel MP, El Zarif M, Alió JL (2021). Corneal stroma regeneration: Preclinical studies. Experimental Eye Research 202: 108314. DOI 10.1016/j.exer.2020.108314.

Assis-Ribas T, Forni MF, Winnischofer SMB, Sogayar MC, TrombettaLima M (2018). Extracellular matrix dynamics during mesenchymal stem cells differentiation. Developmental Biology 437: 63-74. DOI 10.1016/j.ydbio.2018.03.002.

Beckenkamp LR, da Fontoura DMS, Korb VG, de Campos RP, Onzi GR, Iser IC, Bertoni APS, Sévigny J, Lenz G, Wink MR (2020).
Immortalization of mesenchymal stromal cells by TERT affects adenosine metabolism and impairs their immunosuppressive capacity. Stem Cell Reviews and Reports 16: 776-791. DOI 10.1007/s12015-020-09986-5.

Birtwistle L, Chen XM, Pollock C (2021). Mesenchymal stem cellderived extracellular vesicles to the rescue of renal injury. International Journal of Molecular Sciences 22: 6596. DOI 10.3390/ijms22126596.

Brown C, McKee C, Bakshi S, Walker K, Hakman E, Halassy S, Svinarich D, Dodds R, Govind CK, Chaudhry GR (2019). Mesenchymal stem cells: Cell therapy and regeneration potential. Journal of Tissue Engineering and Regenerative Medicine 13: 1738-1755. DOI 10.1002/term.2914.

Bruno S, Deregibus MC, Camussi G (2015). The secretome of mesenchymal stromal cells: Role of extracellular vesicles in immunomodulation. Immunology Letters 168: 154-158. DOI 10.1016/j.imlet.2015.06.007.

Bruno S, Grange C, Deregibus MC, Calogero RA, Saviozzi S et al. (2009). Mesenchymal stem cell-derived microvesicles protect against acute tubular injury. Journal of the American Society of Nephrology 20: 1053-1067. DOI 10.1681/ASN.2008070798.

Caplan AI (1991). Mesenchymal stem cells. Journal of Orthopaedic Research 9: 641-650. DOI 10.1002/jor.1100090504.

Chang C, Yan J, Yao Z, Zhang C, Li X, Mao HQ (2021). Effects of mesenchymal stem cell-derived paracrine signals and their delivery strategies. Advanced Healthcare Materials 10: e2001689. DOI 10.1002/adhm.202001689.

Chen FM, Liu X (2016). Advancing biomaterials of human origin for tissue engineering. Progress in Polymer Science 53: 86-168. DOI 10.1016/j.progpolymsci.2015.02.004.

Chiabotto G, Pasquino C, Camussi G, Bruno S (2020). Molecular pathways modulated by mesenchymal stromal cells and their extracellular vesicles in experimental models of liver fibrosis. Frontiers in Cell and Developmental Biology 8: 594794. DOI 10.3389/fcell.2020.594794.

Cooper LF, Ravindran S, Huang CC, Kang M (2019). A role for exosomes in craniofacial tissue engineering and regeneration. Frontiers in Physiology 10: 1569. DOI 10.3389/fphys.2019.01569.

da Silva ML, Chagastelles PC, Nardi NB (2006). Mesenchymal stem cells reside in virtually all post-natal organs and tissues. Journal of Cell Science 119: 2204-2213. DOI 10.1242/jcs.02932.

Dabrowska S, Andrzejewska A, Janowski M, Lukomska B (2020). Immunomodulatory and regenerative effects of mesenchymal stem cells and extracellular vesicles: Therapeutic outlook for inflammatory and degenerative diseases. Frontiers in Immunology 11: 591065. DOI 10.3389/fimmu.2020.591065.

Daneshmandi L, Shah S, Jafari T, Bhattacharjee M, Momah D, SavehShemshaki N, Lo KWH, Laurencin CT (2020). Emergence of the stem cell secretome in regenerative engineering. Trends in Biotechnology 38: 1373-1384. DOI 10.1016/j.tibtech.2020.04.013.

Dominici M, Le Blanc K, Mueller I, Slaper-Cortenbach I, Marini F, Krause D, Deans R, Keating A, Prockop D, Horwitz E (2006). Minimal criteria for defining multipotent mesenchymal stromal cells. The International Society for Cellular Therapy position statement. Cytotherapy 8: 315-317.

Eiró N, Sendon-Lago J, Seoane S, Bermúdez MA, Lamelas ML, Garcia-Caballero T, Schneider J, Perez-Fernandez R, Vizoso FJ (2014). Potential therapeutic effect of the secretome from human uterine cervical stem cells against both cancer and stromal cells compared with adipose tissue stem cells. Oncotarget 5: 10692-10708. DOI 10.18632/oncotarget.2530. 
Friedenstein AJ, Gorskaja JF, Kulagina NN (1976). Fibroblast precursors in normal and irradiated mouse hematopoietic organs. Experimental Hematology 4: 267-274.

Galgaro BC, Beckenkamp LR, Nunnenkamp M, Korb VG, Naasani LIS, Roszek K, Wink MR (2021). The adenosinergic pathway in mesenchymal stem cell fate and functions. Medicinal Research Reviews 41: 2316-2349. DOI 10.1002/med.21796.

Gholami L, Nooshabadi VT, Shahabi S, Jazayeri M, Tarzemany R, Afsartala Z, Khorsandi K (2021). Extracellular vesicles in bone and periodontal regeneration: Current and potential therapeutic applications. Cell \& Bioscience 11: 16. DOI 10.1186/s13578-020-00527-8.

Groot M, Lee H (2020). Sorting mechanisms for MicroRNAs into extracellular vesicles and their associated diseases. Cells 9: 1044. DOI 10.3390/cells9041044.

Hanson S, D’Souza RN, Hematti P (2014). Biomaterial-mesenchymal stem cell constructs for immunomodulation in composite tissue engineering. Tissue Engineering Part A 20: 21622168. DOI 10.1089/ten.tea.2013.0359.

Harrell CR, Jovicic N, Djonov V, Arsenijevic N, Volarevic V (2019). Mesenchymal stem cell-derived exosomes and other extracellular vesicles as new remedies in the therapy of inflammatory diseases. Cells 8: 1605. DOI 10.3390/cells8121605.

Hu Z, Zhang L, Wang H, Wang Y, Tan Y et al. (2020). Targeted silencing of miRNA-132-3p expression rescues disuse osteopenia by promoting mesenchymal stem cell osteogenic differentiation and osteogenesis in mice. Stem Cell Research \& Therapy 11: 58. DOI 10.1186/s13287-020-1581-6.

Huang R, Qin C, Wang J, Hu Y, Zheng G, Qiu G, Ge M, Tao H, Shu Q, Xu J (2019). Differential effects of extracellular vesicles from aging and young mesenchymal stem cells in acute lung injury. Sedentary Life and Nutrition 11: 7996-8014. DOI 10.18632/aging.102314.

Iaquinta MR, Lanzillotti C, Mazziotta C, Bononi I, Frontini F et al. (2021). The role of microRNAs in the osteogenic and chondrogenic differentiation of mesenchymal stem cells and bone pathologies. Theranostics 11: 6573-6591. DOI $10.7150 /$ thno. 55664 .

Iser IC, Bracco PA, Gonçalves CEI, Zanin RF, Nardi NB, Lenz G, Battastini AMO, Wink MR (2014). Mesenchymal stem cells from different murine tissues have differential capacity to metabolize extracellular nucleotides. Journal of Cellular Biochemistry 115: 1673-1682. DOI 10.1002/jcb.24830.

Kim GB, Shon OJ, Seo MS, Choi Y, Park WT, Lee GW (2021). Mesenchymal stem cell-derived exosomes and their therapeutic potential for osteoarthritis. Biology 10: 285. DOI 10.3390/biology10040285.

Lai RC, Arslan F, Lee MM, Sze NSK, Choo A et al. (2010). Exosome secreted by MSC reduces myocardial ischemia/reperfusion injury. Stem Cell Research 4: 214-222. DOI 10.1016/j. scr.2009.12.003.

Lazarus HM, Haynesworth SE, Gerson SL, Rosenthal NS, Caplan AI (1995). Ex vivo expansion and subsequent infusion of human bone marrow-derived stromal progenitor cells (mesenchymal progenitor cells): Implications for therapeutic use. Bone Marrow Transplantation 16: 557-564.

Li S, Liu J, Liu S, Jiao W, Wang X (2021). Mesenchymal stem cellderived extracellular vesicles prevent the development of osteoarthritis via the circHIPK3/miR-124-3p/MYH9 axis. Journal of Nanobiotechnology 19: 1-20.

Marupanthorn K, Tantrawatpan C, Kheolamai P, Tantikanlayaporn D, Manochantr S (2021). MicroRNA treatment modulates osteogenic differentiation potential of mesenchymal stem cells derived from human chorion and placenta. Scientific Reports 11: 7670. DOI 10.1038/s41598-021-87298-5.

Naasani LIS, Rodrigues C, de Campos RP, Beckenkamp LR, Iser IC, Bertoni APS, Wink MR (2017). Extracellular nucleotide hydrolysis in dermal and limbal mesenchymal stem cells: A source of adenosine production. Journal of Cellular Biochemistry 118: 2430-2442. DOI 10.1002/jcb.25909.

Naasani LIS, Souza AFD, Rodrigues C, Vedovatto S, Azevedo JG, Bertoni APS, da Cruz Fernandes M, Buchner S, Wink MR (2019). Decellularized human amniotic membrane associated with adipose derived mesenchymal stromal cells as a bioscaffold: Physical, histological and molecular analysis. Biochemical Engineering Journal 152: 107366. DOI 10.1016/j.bej.2019.107366.

Novoseletskaya E, Grigorieva O, Nimiritsky P, Basalova N, Eremichev R et al. (2020). Mesenchymal stromal cellproduced components of extracellular matrix potentiate multipotent stem cell response to differentiation stimuli. Frontiers in Cell and Developmental Biology 8: 555378. DOI 10.3389/fcell.2020.555378.

O’Driscoll L (2020). Extracellular vesicles from mesenchymal stem cells as a COVID-19 treatment. Drug Discovery Today 25: 1124-1125. DOI 10.1016/j.drudis.2020.04.022.

Paim TC, Wermuth DP, Bertaco I, Zanatelli C, Naasani LIS, Slaviero M, Driemeier D, Schaeffer L, Wink MR (2020). Evaluation of in vitro and in vivo biocompatibility of iron produced by powder metallurgy. Materials Science \& Engineering: C 115. DOI 10.1016/j.msec.2020.111129.

Rodrigues C, de Assis AM, Moura DJ, Halmenschlager G, Saffi J, Xavier LL, da Cruz Fernandes M, Wink MR (2014). New therapy of skin repair combining adipose-derived mesenchymal stem cells with sodium carboxymethylcellulose scaffold in a preclinical rat model. PLoS One 9: e96241. DOI 10.1371/ journal.pone.0096241.

Rodrigues C, Naasani LIS, Zanatelli C, Paim TC, Azevedo JG, de Lima JC, da Cruz Fernandes M, Buchner S, Wink MR (2019). Bioglass 45S5: Structural characterization of short range order and analysis of biocompatibility with adiposederived mesenchymal stromal cells in vitro and in vivo. Materials Science \& Engineering C, Materials for Biological Applications 103: 109781. DOI 10.1016/j.msec.2019.109781.

Saliminejad K, Khorram Khorshid HR, Soleymani Fard S, Ghaffari SH (2019). An overview of microRNAs: Biology, functions, therapeutics, and analysis methods. Journal of Cellular Physiology 234: 5451-5465. DOI 10.1002/jcp.27486.

Samadi P, Saki S, Manoochehri H, Sheykhhasan M (2021). Therapeutic applications of mesenchymal stem cells: A comprehensive review. Current Stem Cell Research \& Therapy 16: 323-353. DOI 10.2174/1574888X15666200914142709.

Schultz IC, Bertoni APS, Wink MR (2021). Mesenchymal stem cellderived extracellular vesicles carrying miRNA as a potential multi target therapy to COVID-19: An in silico analysis. Stem Cell Reviews and Reports 17: 341-356. DOI 10.1007/ s12015-021-10122-0.

Senegaglia AC, Rebelatto CLK, Franck CL, Lima JS, Boldrini-Leite LM et al. (2021). Combined use of tocilizumab and mesenchymal stromal cells in the treatment of severe COVID-19: Case report. Cell Transplantation 30: 9636897211021008.

Shi Q, Sun B, Wang D, Zhu Y, Zhao X, Yang X, Zhang Y (2020). Circ6401, a novel circular RNA, is implicated in repair of the damaged endometrium by Wharton's jelly-derived 
mesenchymal stem cells through regulation of the miR-29b-15p/RAP1B axis. Stem Cell Research \& Therapy 11: 1-16.

Sierra-Sánchez Á., Montero-Vilchez T, Quiñones-Vico MI, SanchezDiaz M, Arias-Santiago S (2021). Current advanced therapies based on human mesenchymal stem cells for skin diseases. Frontiers in Cell and Developmental Biology 9: 643125. DOI 10.3389/fcell.2021.643125.

Song N, Scholtemeijer M, Shah K (2020). Mesenchymal stem cell immunomodulation: Mechanisms and therapeutic potential. Trends in Pharmacological Sciences 41: 653-664. DOI 10.1016/j.tips.2020.06.009.

Sous Naasani LI, Rodrigues C, Azevedo JG, Damo Souza AF, Buchner S, Wink MR (2018). Comparison of human denuded amniotic membrane and porcine small intestine submucosa as scaffolds for limbal mesenchymal stem cells. Stem Cell Reviews and Reports 14: 744-754. DOI 10.1007/s12015-018-9819-8.

Sun B, Shi L, Shi Q, Jiang Y, Su Z, Yang X, Zhang Y (2018). Circular RNAs are abundantly expressed and upregulated during repair of the damaged endometrium by Wharton's jellyderived mesenchymal stem cells. Stem Cell Research \& Therapy 9: 314. DOI 10.1186/s13287-018-1046-3.

Tavassoli M, Crosby WH (1968). Transplantation of marrow to extramedullary sites. Science 161: 54-56. DOI 10.1126/ science.161.3836.54.
Vedovatto S, Facchini JC, Batista RK, Paim TC, Lionzo MIZ, Wink MR (2020). Development of chitosan, gelatin and liposome film and analysis of its biocompatibility in vitro. International Journal of Biological Macromolecules 160: 750-757. DOI 10.1016/j.ijbiomac.2020.05.229.

Vieira NM, Zucconi E, Bueno CR Jr, Secco M, Suzuki MF, Bartolini P, Vainzof M, Zatz M (2010). Human multipotent mesenchymal stromal cells from distinct sources show different in vivo potential to differentiate into muscle cells when injected in dystrophic mice. Stem Cell Reviews and Reports 6: 560-566. DOI 10.1007/s12015-010-9187-5.

Vizoso FJ, Eiro N, Cid S, Schneider J, Perez-Fernandez R (2017). Mesenchymal stem cell secretome: Toward cell-free therapeutic strategies in regenerative medicine. International Journal of Molecular Sciences 18: 9. DOI 10.3390/ijms18091852.

Yang Y, Ye Y, Su X, He J, Bai W, He X (2017). MSCs-derived exosomes and neuroinflammation, neurogenesis and therapy of traumatic brain injury. Frontiers in Cellular Neuroscience 11: 55. DOI 10.3389/fncel.2017.00055.

Zuk PA, Zhu M, Mizuno H, Huang J, William Futrell J, Katz AJ, Benhaim P, Peter Lorenz H, Hedrick MH (2001). Multilineage cells from human adipose tissue: Implications for cell-based therapies. Tissue Engineering 7: 211-228. DOI 10.1089/107632701300062859.

TABLE S1

Clinical trials with mesenchymal stem cells.

\begin{tabular}{|c|c|c|c|c|c|}
\hline $\begin{array}{l}\text { Cell type/ } \\
\text { source }\end{array}$ & Study brief title & Condition & Interventions & $\begin{array}{l}\text { Phase } \\
\text { status }\end{array}$ & Reference \\
\hline \multirow{8}{*}{$\begin{array}{l}\text { Autologous } \\
\text { Bone } \\
\text { Marrow- } \\
\text { derived } \\
\text { MSCs }\end{array}$} & $\begin{array}{l}\text { Combination of autologous MSC and } \\
\text { HSC infusion in patients with } \\
\text { decompensated cirrhosis }\end{array}$ & Cirrhosis & $\begin{array}{l}\text { - CD34 and MSC infusion } \\
\text { - Standard of care for cirrhosis } \\
\text { management }\end{array}$ & $\begin{array}{l}\text { Phase } 4 \\
\text { Completed }\end{array}$ & NCT0424368 \\
\hline & $\begin{array}{l}\text { Bone regeneration with mesenchymal } \\
\text { stem cells }\end{array}$ & $\begin{array}{l}\text { Mandibular } \\
\text { Fractures }\end{array}$ & - Application of MSCs & $\begin{array}{l}\text { Phase } 3 \\
\text { Completed }\end{array}$ & NCT02755922 \\
\hline & $\begin{array}{l}\text { Safety and efficacy of autologous } \\
\text { mesenchymal stem cells in chronic } \\
\text { spinal cord injury }\end{array}$ & $\begin{array}{l}\text { Spinal Cord } \\
\text { Injury }\end{array}$ & $\begin{array}{l}\text { - Posterior cervical laminectomy } \\
\text { and MSCs transplantation }\end{array}$ & $\begin{array}{l}\text { Phase } 2 / 3 \\
\text { Completed }\end{array}$ & NCT01676441 \\
\hline & $\begin{array}{l}\text { Safety and efficacy of intracoronary adult } \\
\text { human mesenchymal stem cells after } \\
\text { acute myocardial infarction }\end{array}$ & $\begin{array}{l}\text { Acute } \\
\text { Myocardial } \\
\text { Infarction }\end{array}$ & $\begin{array}{l}\text { - Intracoronary injection of } \\
\text { MSCs } \\
\text { - Control (aspirin and } \\
\text { clopidogrel) }\end{array}$ & $\begin{array}{l}\text { Phase } 2 / 3 \\
\text { Completed }\end{array}$ & NCT01392105 \\
\hline & $\begin{array}{l}\text { A comparative study of } 2 \text { doses of BM } \\
\text { autologous } \mathrm{H}-\mathrm{MSC}+\text { biomaterial } v s \text {. iliac } \\
\text { crest autograft for bone healing in non- } \\
\text { union }\end{array}$ & $\begin{array}{l}\text { Non-Union } \\
\text { Fracture }\end{array}$ & $\begin{array}{l}\text { - MSCs low dose + biphasic } \\
\text { calcium phosphate (BCP) } \\
\text { - MSCs high dose + BCP } \\
\text { - Control (Autologous iliac crest } \\
\text { graft) }\end{array}$ & $\begin{array}{l}\text { Phase } 3 \\
\text { Recruiting }\end{array}$ & NCT03325504 \\
\hline & $\begin{array}{l}\text { To evaluate the efficacy and safety of } \\
\text { HEARTICELGRAM }{ }^{\circledR} \text {-AMI in patients } \\
\text { with acute myocardial infarction }\end{array}$ & $\begin{array}{l}\text { Acute } \\
\text { Myocardial } \\
\text { Infarction }\end{array}$ & $\begin{array}{l}\text { - MSCs and contemporary drug } \\
\text { treatment } \\
\text { - Control (contemporary drug } \\
\text { treatment) }\end{array}$ & $\begin{array}{l}\text { Phase } 3 \\
\text { Recruiting }\end{array}$ & NCT01652209 \\
\hline & $\begin{array}{l}\text { Clinical trial to evaluate the efficacy and } \\
\text { safety of Cellgram-LC administration in } \\
\text { patients with alcoholic cirrhosis }\end{array}$ & $\begin{array}{l}\text { Alcoholic } \\
\text { Cirrhosis }\end{array}$ & $\begin{array}{l}\text { - Injection of MSCs in hepatic } \\
\text { artery } \\
\text { - Best supportive care }\end{array}$ & $\begin{array}{l}\text { Phase } 3 \\
\text { Not yet } \\
\text { recruiting }\end{array}$ & NCT04689152 \\
\hline & $\begin{array}{l}\text { Bone marrow mesenchymal stem cells } \\
\text { transfer in patients with ST-segment } \\
\text { elevation myocardial infarction }\end{array}$ & $\begin{array}{l}\text { Myocardial } \\
\text { Infarction }\end{array}$ & $\begin{array}{l}\text { - Bone marrow MSC transfer } \\
\text { - Best medical treatment } \\
\text { - Percutaneous coronary } \\
\text { intervention }\end{array}$ & $\begin{array}{l}\text { Phase } 2 / 3 \\
\text { Completed }\end{array}$ & NCT04421274 \\
\hline
\end{tabular}


Table S1 (continued).

\begin{tabular}{|c|c|c|c|c|c|}
\hline $\begin{array}{l}\text { Cell type/ } \\
\text { source }\end{array}$ & Study brief title & Condition & Interventions & $\begin{array}{l}\text { Phase } \\
\text { status }\end{array}$ & Reference \\
\hline & $\begin{array}{l}\text { Parkinson's disease therapy using cell } \\
\text { technology }\end{array}$ & $\begin{array}{l}\text { Transplantation: } \\
\text { Mesenchymal } \\
\text { Stem Cell }\end{array}$ & $\begin{array}{l}\text { - MSCs transplantation } \\
\text { - Placebo }\end{array}$ & $\begin{array}{l}\text { Phase } 2 / 3 \\
\text { Recruiting }\end{array}$ & NCT04146519 \\
\hline & $\begin{array}{l}\text { Bone marrow derived stem cell } \\
\text { transplantation in T2DM }\end{array}$ & $\begin{array}{l}\text { Type } 2 \text { Diabetes } \\
\text { Mellitus }\end{array}$ & $\begin{array}{l}\text { - MSCs transplantation } \\
\text { - MNC's transplantation } \\
\text { - Control }\end{array}$ & $\begin{array}{l}\text { Phase } 3 \\
\text { Recruiting }\end{array}$ & NCT01759823 \\
\hline & $\begin{array}{l}\text { Efficacy in alveolar bone regeneration } \\
\text { with autologous mscs and biomaterial in } \\
\text { comparison to autologous bone grafting }\end{array}$ & $\begin{array}{l}\text { Alveolar Bone } \\
\text { Atrophy }\end{array}$ & $\begin{array}{l}\text { - MSC combined with BCP } \\
\text { - Autologous bone graft }\end{array}$ & $\begin{array}{l}\text { Phase } 3 \\
\text { Recruiting }\end{array}$ & NCT04297813 \\
\hline & $\begin{array}{l}\text { Evaluatiton the efficacy and safety of } \\
\text { mutiple lenzumestrocel (neuronata-r }{ }^{\circledR} \\
\text { inj.) Treatment in patients with ALS }\end{array}$ & $\begin{array}{l}\text { Amyotrophic } \\
\text { Lateral Sclerosis }\end{array}$ & $\begin{array}{l}\text { - Lenzumestrocel } \\
\text { - Riluzole } \\
\text { - Placebo }\end{array}$ & $\begin{array}{l}\text { Phase } 3 \\
\text { Recruiting }\end{array}$ & NCT04745299 \\
\hline & $\begin{array}{l}\text { Cardiovascular clinical project to } \\
\text { evaluate the regenerative capacity of } \\
\text { cardiocell in patients with acute } \\
\text { myocardial infarction (AMI) }\end{array}$ & $\begin{array}{l}\text { Myocardial } \\
\text { Infarction }\end{array}$ & $\begin{array}{l}\text { - MSCs administration } \\
\text { - Placebo }\end{array}$ & $\begin{array}{l}\text { Phases } 2 \\
\text { and } 3 \\
\text { Completed }\end{array}$ & NCT03404063 \\
\hline & $\begin{array}{l}\text { Safety and efficacy of repeated } \\
\text { administrations of NurOwn }{ }^{\circledR} \text { in ALS } \\
\text { patients }\end{array}$ & $\begin{array}{l}\text { Amyotrophic } \\
\text { Lateral Sclerosis } \\
\text { (ALS) }\end{array}$ & $\begin{array}{l}\text { - NurOwn }{ }^{\circledR} \text { (MSC-NTF cells) } \\
\text { - Placebo }\end{array}$ & $\begin{array}{l}\text { Phase } 3 \\
\text { Completed }\end{array}$ & NCT03280056 \\
\hline & $\begin{array}{l}\text { Stem cell therapy for treatment of female } \\
\text { stress urinary incontinence }\end{array}$ & $\begin{array}{l}\text { Urinary } \\
\text { Incontinence, } \\
\text { Stress }\end{array}$ & $\begin{array}{l}\text { - MSCs injection } \\
\text { - Surgery (TVT) }\end{array}$ & $\begin{array}{l}\text { Phase } 3 \\
\text { Completed }\end{array}$ & NCT02334878 \\
\hline & $\begin{array}{l}\text { Transplantation of bone marrow derived } \\
\text { mesenchymal stem cells in affected knee } \\
\text { osteoarthritis by rheumatoid arthritis }\end{array}$ & $\begin{array}{l}\text { Rheumatoid } \\
\text { Arthritis }\end{array}$ & $\begin{array}{l}\text { - MSCs transplantation } \\
\text { - Placebo }\end{array}$ & $\begin{array}{l}\text { Phase } 2 / 3 \\
\text { Completed }\end{array}$ & NCT01873625 \\
\hline & $\begin{array}{l}\text { Bone marrow } v s \text {. adipose autologous } \\
\text { mesenchymal stem cells for the } \\
\text { treatment of knee osteoarthritis }\end{array}$ & $\begin{array}{l}\text { Knee } \\
\text { Osteoarthritis }\end{array}$ & $\begin{array}{l}\text { - Bone marrow derived MSC } \\
\text { - Adipose derived MSC } \\
\text { - Bone marrow \& adipose } \\
\text { derived MSC injection }\end{array}$ & $\begin{array}{l}\text { Phase } 3 \\
\text { Not yet } \\
\text { recruiting }\end{array}$ & NCT04351932 \\
\hline & $\begin{array}{l}\text { Multicenter trial of stem cell therapy for } \\
\text { osteoarthritis (miles) }{ }^{*}\end{array}$ & Osteoarthritis & $\begin{array}{l}\text { - Autologous Bone Marrow } \\
\text { Concentrate } \\
\text { - Adipose-derived Stromal } \\
\text { Vascular Fraction } \\
\text { - Umbilical Cord Tissue } \\
\text { - Corticosteroid injection }\end{array}$ & $\begin{array}{l}\text { Phase } 3 \\
\text { Active, not } \\
\text { recruiting }\end{array}$ & NCT03818737 \\
\hline \multirow[t]{5}{*}{$\begin{array}{l}\text { Allogeneic } \\
\text { Bone } \\
\text { Marrow- } \\
\text { derived } \\
\text { MSCs }\end{array}$} & $\begin{array}{l}\text { Mesenchymal stem cell infusion in } \\
\text { haploidentical hematopoietic stem cell } \\
\text { transplantation in patients with } \\
\text { hematological malignancies }\end{array}$ & $\begin{array}{l}\text { Hematopoietic } \\
\text { Stem Cell } \\
\text { Transplantation }\end{array}$ & $\begin{array}{l}\text { - MSCs infusion } \\
\text { - Cyclophosphamide } \\
\text { administration }\end{array}$ & $\begin{array}{l}\text { Phase } 3 \\
\text { Completed }\end{array}$ & NCT03106662 \\
\hline & $\begin{array}{l}\text { A study of allogeneic low oxygen } \\
\text { mesenchymal bone marrow cells in } \\
\text { subjects with myocardial infarction }\end{array}$ & $\begin{array}{l}\text { Myocardial } \\
\text { Infarction }\end{array}$ & $\begin{array}{l}\text { - MSCs administration } \\
\text { - Placebo }\end{array}$ & $\begin{array}{l}\text { Phase } 3 \\
\text { Completed }\end{array}$ & NCT02672267 \\
\hline & $\begin{array}{l}\text { Left ventricular assist device combined } \\
\text { with allogeneic mesenchymal stem cells } \\
\text { implantation in patients with end-stage } \\
\text { heart failure. }\end{array}$ & $\begin{array}{l}\text { Heart Failure } \\
\text { Ischemic } \\
\text { Cardiomyopathy }\end{array}$ & - MSCs implantation & $\begin{array}{l}\text { Phase } 2 / 3 \\
\text { Active, not } \\
\text { recruiting }\end{array}$ & NCT01759212 \\
\hline & MSCS in COVID-19 ARDS & $\begin{array}{l}\text { Acute } \\
\text { Respiratory } \\
\text { Distress } \\
\text { Syndrom, } \\
\text { COVID }\end{array}$ & $\begin{array}{l}\text { - MSCs infusion } \\
\text { - Placebo }\end{array}$ & $\begin{array}{l}\text { Phase } 3 \\
\text { Active, not } \\
\text { recruiting }\end{array}$ & NCT04371393 \\
\hline & $\begin{array}{l}\text { Evaluation of PROCHYMAl }{ }^{\circledR} \text { adult } \\
\text { human stem cells for treatment-resistant } \\
\text { moderate-to-severe crohn's disease }\end{array}$ & Crohn’s Disease & $\begin{array}{l}\text { - Ex Vivo Cultured Adult } \\
\text { Human Mesenchymal Stem } \\
\text { Cells-Prochymal }^{\circledR} \\
\text { - Placebo }\end{array}$ & $\begin{array}{l}\text { Phase } 3 \\
\text { Completed }\end{array}$ & NCT00482092 \\
\hline
\end{tabular}


Table S1 (continued).

\begin{tabular}{|c|c|c|c|c|c|}
\hline $\begin{array}{l}\text { Cell type/ } \\
\text { source }\end{array}$ & Study brief title & Condition & Interventions & $\begin{array}{l}\text { Phase } \\
\text { status }\end{array}$ & Reference \\
\hline \multirow{11}{*}{$\begin{array}{l}\text { Autologous } \\
\text { Adipose- } \\
\text { derived } \\
\text { MSCs }\end{array}$} & $\begin{array}{l}\text { Extended evaluation of PROCHYMAL }{ }^{\circledR} \\
\text { adult human stem cells for treatment- } \\
\text { resistant moderate-to-severe crohn's } \\
\text { disease }\end{array}$ & Crohn's Disease & $\begin{array}{l}\text { - Placebo } \\
\text { - Ex Vivo Cultured Adult } \\
\text { Human Mesenchymal Stem } \\
{\text { Cells- Prochymal }{ }^{\circledR}}\end{array}$ & $\begin{array}{l}\text { Phase } 3 \\
\text { Completed }\end{array}$ & NCT00543374 \\
\hline & $\begin{array}{l}\text { Evaluation of PROCHYMAL }{ }^{\circledR} \text { for } \\
\text { treatment-refractory moderate-to-severe } \\
\text { crohn's disease }\end{array}$ & Crohn's Disease & $\begin{array}{l}\text { - Ex Vivo Cultured Adult } \\
\text { Human Mesenchymal Stem } \\
\text { Cells- Prochymal }^{\circledR}\end{array}$ & $\begin{array}{l}\text { Phase } 3 \\
\text { Completed }\end{array}$ & NCT01233960 \\
\hline & $\begin{array}{l}\text { Efficacy and safety of PROCHYMAL } \\
\text { infusion in combination with } \\
\text { corticosteroids for the treatment of } \\
\text { newly diagnosed acute graft versus host } \\
\text { disease (GVHD) }\end{array}$ & $\begin{array}{l}\text { Graft } v s . \text { Host } \\
\text { Disease }\end{array}$ & $\begin{array}{l}\text { - Ex Vivo Cultured Adult } \\
\text { Human Mesenchymal Stem } \\
{\text { Cells- Prochymal }{ }^{\circledR}} \\
\text { - Placebo }\end{array}$ & $\begin{array}{l}\text { Phase } 3 \\
\text { Completed }\end{array}$ & NCT00562497 \\
\hline & $\begin{array}{l}\text { Clinical study to evaluate efficacy and } \\
\text { safety of ASC and fibringlue or fibringlue } \\
\text { in patients with crohn's fistula }\end{array}$ & Crohn's Fistula & $\begin{array}{l}\text { - MSCs injection } \\
\text { - Fibrin Glue }\end{array}$ & $\begin{array}{l}\text { Phase } 3 \\
\text { Recruiting }\end{array}$ & NCT04612465 \\
\hline & $\begin{array}{l}\text { A phase } 2 \mathrm{~b} / 3 \mathrm{a} \text { study to evaluate the } \\
\text { efficacy and safety of JOINTSTEM in } \\
\text { patients diagnosed as knee osteoarthritis }\end{array}$ & $\begin{array}{l}\text { Osteoarthritis, } \\
\text { Knee }\end{array}$ & $\begin{array}{l}\text { - JOINTSTEM } \\
\text { - Placebo Control }\end{array}$ & $\begin{array}{l}\text { Phases } 2 \\
\text { and } 3 \\
\text { Recruiting }\end{array}$ & NCT04368806 \\
\hline & $\begin{array}{l}\text { A phase } 3 \text { study to evaluate the efficacy } \\
\text { and safety of JOINTSTEM in treatment } \\
\text { of osteoarthritis }\end{array}$ & $\begin{array}{l}\text { Degenerative } \\
\text { Arthritis } \\
\text { Knee } \\
\text { Osteoarthritis }\end{array}$ & $\begin{array}{l}\text { - JOINTSTEM } \\
\text { - Saline }\end{array}$ & $\begin{array}{l}\text { Phase } 3 \\
\text { Completed }\end{array}$ & NCT03990805 \\
\hline & $\begin{array}{l}\text { Clinical trial to evaluate the efficacy and } \\
\text { safety of stem cells }\end{array}$ & Anal Fistula & $\begin{array}{l}\text { - MSCs + fibrin glue } \\
\text { - fibrin glue }\end{array}$ & $\begin{array}{l}\text { Phase } 3 \\
\text { Completed }\end{array}$ & NCT01803347 \\
\hline & $\begin{array}{l}\text { Effects of a mat versus steroid injection } \\
\text { in knee osteoarthritis (sta mat-knee } \\
\text { study) }\end{array}$ & $\begin{array}{l}\text { Knee } \\
\text { Osteoarthritis }\end{array}$ & $\begin{array}{l}\text {-Microfragmented Adipose } \\
\text { Tissue Transplant } \\
\text { - Corticosteroid injection }\end{array}$ & $\begin{array}{l}\text { Phase } 3 \\
\text { Recruiting }\end{array}$ & NCT04230902 \\
\hline & $\begin{array}{l}\text { Follow-up study for participants of } \\
\text { JOINTSTEM }\end{array}$ & $\begin{array}{l}\text { Knee } \\
\text { Osteoarthritis }\end{array}$ & $\begin{array}{l}\text { - JOINTSTEM } \\
\text { - Saline }\end{array}$ & $\begin{array}{l}\text { Phase } 3 \\
\text { Enrolling } \\
\text { by } \\
\text { invitation }\end{array}$ & NCT04427930 \\
\hline & $\begin{array}{l}\text { Bone marrow versus adipose autologous } \\
\text { mesenchymal stem cells for the } \\
\text { treatment of knee osteoarthritis }\end{array}$ & $\begin{array}{l}\text { Knee } \\
\text { Osteoarthritis }\end{array}$ & $\begin{array}{l}\text { - Bone marrow derived-MSC } \\
\text { - Adipose derived MSC } \\
\text { - Bone marrow \& adipose } \\
\text { derived MSC injection }\end{array}$ & $\begin{array}{l}\text { Phase } 3 \\
\text { Not yet } \\
\text { recruiting }\end{array}$ & NCT04351932 \\
\hline & $\begin{array}{l}\text { Multicenter trial of stem cell therapy for } \\
\text { osteoarthritis (miles)* }\end{array}$ & Osteoarthritis & $\begin{array}{l}\text { - Autologous Bone Marrow } \\
\text { Concentrate } \\
\text { - Adipose-derived Stromal } \\
\text { Vascular Fraction } \\
\text { - Umbilical Cord Tissue } \\
\text { - Corticosteroid injection }\end{array}$ & $\begin{array}{l}\text { Phase } 3 \\
\text { Active, not } \\
\text { recruiting }\end{array}$ & NCT03818737 \\
\hline \multirow{3}{*}{$\begin{array}{l}\text { Allogeneic } \\
\text { Adipose- } \\
\text { derived } \\
\text { MSC }\end{array}$} & $\begin{array}{l}\text { Clinical study to evaluate efficacy and } \\
\text { safety of ALLO-ASC-DFU in patients } \\
\text { with diabetic foot ulcers. }\end{array}$ & $\begin{array}{l}\text { Diabetic Foot } \\
\text { Ulcer }\end{array}$ & $\begin{array}{l}\text { - ALLO-ASC-DFU } \\
\text { - Vehicle sheet }\end{array}$ & $\begin{array}{l}\text { Phase } 3 \\
\text { Active, not } \\
\text { recruiting }\end{array}$ & NCT03370874 \\
\hline & $\begin{array}{l}\text { Adipose derived mesenchymal stem cells } \\
\text { for induction of remission in perianal } \\
\text { fistulizing crohn's disease }\end{array}$ & Crohn's Disease & $\begin{array}{l}\text { - MSCs injection } \\
\text { - Saline solution }\end{array}$ & $\begin{array}{l}\text { Phase } 3 \\
\text { Completed }\end{array}$ & NCT01541579 \\
\hline & $\begin{array}{l}\text { Clinical study to evaluate efficacy and } \\
\text { safety of ALLO-ASC-DFU in patients } \\
\text { with diabetic wagner grade } 2 \text { foot ulcers }\end{array}$ & $\begin{array}{l}\text { Diabetic Foot } \\
\text { Ulcer }\end{array}$ & $\begin{array}{l}\text { - Hydrogel sheet containing } \\
\text { MSC } \\
\text { - Vehicle Sheet without MSCs }\end{array}$ & $\begin{array}{l}\text { Phase } 3 \\
\text { Recruiting }\end{array}$ & NCT04569409 \\
\hline
\end{tabular}


Table S1 (continued).

\begin{tabular}{|c|c|c|c|c|c|}
\hline $\begin{array}{l}\text { Cell type/ } \\
\text { source }\end{array}$ & Study brief title & Condition & Interventions & $\begin{array}{l}\text { Phase } \\
\text { status }\end{array}$ & Reference \\
\hline \multirow{4}{*}{$\begin{array}{l}\text { Allogeneic } \\
\text { Umbilical } \\
\text { Cord- } \\
\text { derived } \\
\text { MSCs }\end{array}$} & $\begin{array}{l}\text { Different efficacy between rehabilitation } \\
\text { therapy and stem cells transplantation in } \\
\text { patients with sci in China }\end{array}$ & $\begin{array}{l}\text { Spinal Cord } \\
\text { Injury }\end{array}$ & $\begin{array}{l}\text { - Cell therapy } \\
\text { - Cehabilitation }\end{array}$ & $\begin{array}{l}\text { Phase } 3 \\
\text { Completed }\end{array}$ & NCT01873547 \\
\hline & $\begin{array}{l}\text { The effectiveness of adding allogenic } \\
\text { stem cells after traditional treatment of } \\
\text { osteochondral lesions of the talus }\end{array}$ & $\begin{array}{l}\text { Osteochondral } \\
\text { Fracture of Talus }\end{array}$ & $\begin{array}{l}\text { - Platelet-poor plasma scaffold } \\
\text { embedded in MSCs added to the } \\
\text { traditional treatment for } \\
\text { osteochondral lesions } \\
\text { - Traditional treatment } \\
\text { (debridement and } \\
\text { microfracture) }\end{array}$ & $\begin{array}{l}\text { Phase } 3 \\
\text { Recruiting }\end{array}$ & NCT03905824 \\
\hline & $\begin{array}{l}\text { Efficacy of stem cell transplantation } \\
\text { compared to rehabilitation treatment of } \\
\text { patients with cerebral paralysis }\end{array}$ & Cerebral Palsy & $\begin{array}{l}\text { - Rehabilitation } \\
\text { - MSCs injection }\end{array}$ & $\begin{array}{l}\text { Phase } 3 \\
\text { Completed }\end{array}$ & NCT01929434 \\
\hline & $\begin{array}{l}\text { Efficacy and safety of UC-MSCS for the } \\
\text { treatment of steroid-resistant agvhd } \\
\text { following allo-hsct }\end{array}$ & $\begin{array}{l}\text { Graft vs. Host } \\
\text { Disease }\end{array}$ & $\begin{array}{l}\text { - MSCs and Anti-CD25 mAb } \\
\text { - Anti-CD25 mAb }\end{array}$ & $\begin{array}{l}\text { Phase } 3 \\
\text { Not yet } \\
\text { Recruiting }\end{array}$ & NCT04738981 \\
\hline $\begin{array}{l}\text { Allogeneic } \\
\text { Wharton's }\end{array}$ & $\begin{array}{l}\text { Management of retinitis pigmentosa by } \\
\text { mesenchymal stem cells by Wharton's }\end{array}$ & $\begin{array}{l}\text { Retinitis } \\
\text { Pigmentosa }\end{array}$ & - MSCs administration & $\begin{array}{l}\text { Phase } 3 \\
\text { Completed }\end{array}$ & NCT04224207 \\
\hline
\end{tabular}

$\begin{array}{lll}\text { Wharton's mesenchymal stem cells by Wharton's } & \text { Pigmentosa } \\ \text { Jelly derived jelly derived mesenchymal stem cells } & \text { Inherited Retinal }\end{array}$

$$
\text { MSCs }
$$

Randomized clinical trial to evaluate the Heart Failure regenerative capacity of cardiocell in patients with chronic ischaemic heart failure (CIHF)

Therapy of toxic optic neuropathy via combination of stem cells with electromagnetic stimulation

Cardiovascular clinical project to evaluate the regenerative capacity of cardiocell in patients with no-option critical limb ischemia (n-o cli)

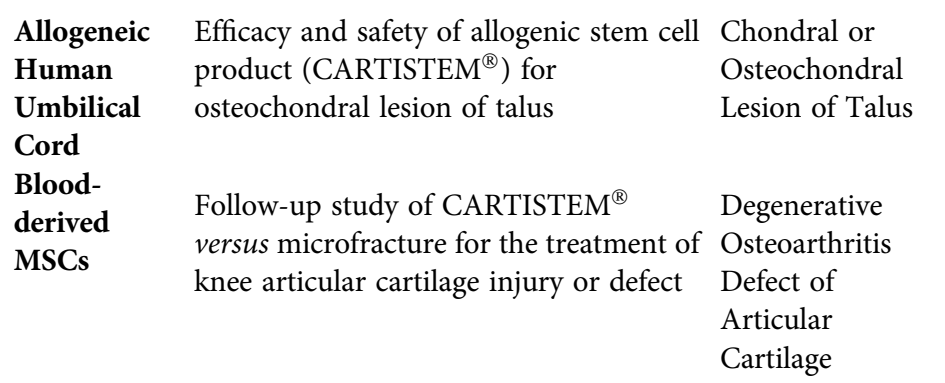

Multicenter trial of stem cell therapy for Osteoarthritis osteoarthritis (MILES)

Study to compare efficacy and safety of CARTISTEM and microfracture in patients with knee articular cartilage injury

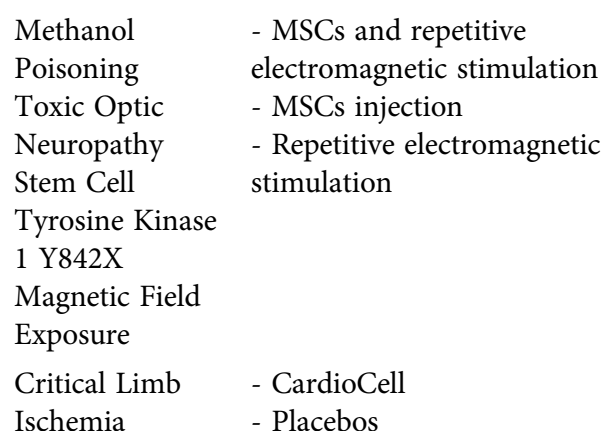

- CARTISTEM ${ }^{\circledR}$

(product based MSCs)

- Microfracture

- CARTISTEM

- Microfracture

- Autologous Bone Marrow Concentrate

- Adipose-derived Stromal

Vascular Fraction

- Umbilical Cord Tissue

- Corticosteroid injection

Cartilage Injury - Cartistem

Osteoarthritis - Microfracture treatment
Phases 2

and 3

Completed

Phase 3

NCT04877067

Completed

Phases 2

NCT03423732

and 3

Active, not

recruiting

Phase 3

NCT04310215

Active, not

recruiting

Phase 3

Completed

NCT01626677

Completed

Phase 3

NCT03818737

Active, not

recruiting

Phase 3 NCT01041001

Completed 
Table S1 (continued).

\begin{tabular}{|c|c|c|c|c|c|}
\hline $\begin{array}{l}\text { Cell type/ } \\
\text { source }\end{array}$ & Study brief title & Condition & Interventions & $\begin{array}{l}\text { Phase } \\
\text { status }\end{array}$ & Reference \\
\hline $\begin{array}{l}\text { Autologous } \\
\text { Deciduous } \\
\text { Dental } \\
\text { Pulp- } \\
\text { derived } \\
\text { MSCs }\end{array}$ & $\begin{array}{l}\text { Bone tissue engineering with dental pulp } \\
\text { stem cells for alveolar cleft repair }\end{array}$ & $\begin{array}{l}\text { Cleft Lip and } \\
\text { Palate }\end{array}$ & $\begin{array}{l}\text { - MSCs associated with } \\
\text { hydroxyapatita/collagen } \\
\text { - Iliac crest autogenous bone } \\
\text { graft }\end{array}$ & $\begin{array}{l}\text { Phase } 3 \\
\text { Completed }\end{array}$ & NCT03766217 \\
\hline \multirow[t]{4}{*}{$\begin{array}{l}\text { Non- } \\
\text { Informed }\end{array}$} & $\begin{array}{l}\text { Comparative study of strategies for } \\
\text { management of Duchenne Myopathy } \\
\text { (DM) }\end{array}$ & Myopathy & $\begin{array}{l}\text { - Sildenafil (Phosphodiesterase } \\
\text { inhibitors } \\
\text { - Prednisolone (Steroids) } \\
\text { - MSC transplantation }\end{array}$ & $\begin{array}{l}\text { Phase } 4 \\
\text { Not yet } \\
\text { recruiting }\end{array}$ & NCT03633565 \\
\hline & $\begin{array}{l}\text { Mesenchymal stem cell therapy for } \\
\text { SARS-CoV-2-related Acute Respiratory } \\
\text { Distress Syndrome }\end{array}$ & COVID-19 & $\begin{array}{l}\text { - MSC therapy protocol } 1 \\
\text {-MSC therapy protocol } 2\end{array}$ & $\begin{array}{l}\text { Phase } 2 / 3 \\
\text { Recruiting }\end{array}$ & NCT04366063 \\
\hline & MSC for Severe aGVHD & $\begin{array}{l}\text { Steroid-resistant } \\
\text { Severe aGVHD }\end{array}$ & - MSCs & $\begin{array}{l}\text { Phase } 2 / 3 \\
\text { Recruiting }\end{array}$ & NCT03631589 \\
\hline & $\begin{array}{l}\text { Clinical extension study for safety and } \\
\text { efficacy evaluation of Cellavita-HD } \\
\text { Administration in Huntington's patients }\end{array}$ & $\begin{array}{l}\text { Huntington } \\
\text { Disease }\end{array}$ & - Injection of Cellavita-HD & $\begin{array}{l}\text { Phase } 2 / 3 \\
\text { Active, not } \\
\text { Recruiting }\end{array}$ & NCT04219241 \\
\hline
\end{tabular}

Notes: Free text terms searched in ClinicalTrials.gov on August 2021: "Mesenchymal stem cells" or "Mesenchymal stromal cells" and "extracellular vesicles" or Exosomes or microvesicles, with no language or time restrictions. Studies with status Recruiting, not yet recruiting, active, not recruiting, completed, enrolling by invitation and terminated studies were included. * Studies involving 2 or more MSCs types. 